Historic, Archive Document

Do not assume content reflects current scientific knowledge, policies, or practices. 

IRIECOEITVDD

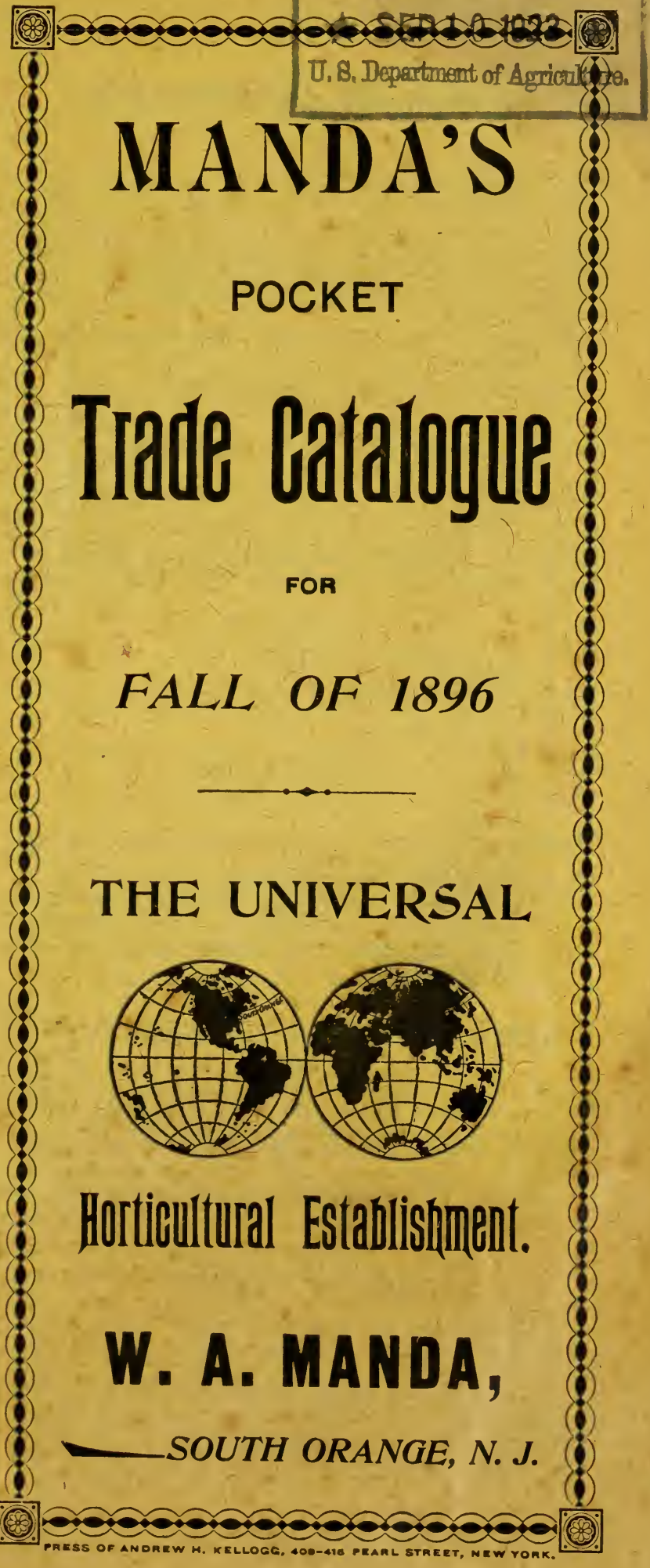




\section{Advice to Customers.}

Please send in your orders early.

Please induce your friends to send their orders with yours.

Please give me ample time to fill your order carefully.

PLEASE add enough to cover postage if ordered by mail.

PLEASE write your name and address plainly.

PleAse give mode of shipment; express is recommended.

Please say if I can send other kinds for any out of stock.

PLEASE register all letters containing money.

What I Do-Everything in my power to satisfy customers.

What I Do-Give my customers the value of their money.

WHAT I Do-Offer best quality at lowest living prices.

WhaT I Do-Guarantee safe arrival of goods by express.

What I Do-Rectify all just claims if made at once.

What I Do Not Do-Guarantee crops. See "Disclaimer."

What I DO NoT Do-Offer anything I hare no faith in.

WHAT I DO NOT DO-Offer $\$ 2$ for $\$ 1$, because I could not do it honestly.

What I DO NOT Do-Substitute, unless given the privilege.

WhAT I DO NOT DO-Guarantee goods sent by mail or freight.

WhAT I DO NOT DO-Take responsibility for money sent in unregistered letters.

What I DO Not Do-Not responsible for failure or shortage of crops, stock being exhausted when order is filled, or any accidents or delays in delivery beyond my control, and I accept orders on those couditions only.

\section{WHILE I EXERCISE THE GREATEST} CARE

To have all seeds, plants, and bulbs pure and reliable, I do not give any warranty, express or implied. If the purchaser does not accept them on these terms and conditions, they must be returned at once. and the money that has been paid for the same will be refunded.

\section{TERMS OF PAYMENT.}

Accounts are due quarterly, irrespective of date of purchase : January ist, April ist, July ist, and October Ist.

Parties which I have not had the pleasure of doing business with previously, will please send remittance or good reference. cash.

Five per cent. discount allowed on all orders with 


\section{To the Florists of America.}

With this, my fourth Wholesale Catalogue, I thank my numerous customers for their patronage, and again inform them that $I$ have severed all active connection with the incorporated stock company of Pitcher \& Manda, and have established myself in South Orange, N. J. I am well equipped to furnish you anything in the Horticultural line, Seeds, Bulbs or Piants. In this Catalogue I have only enumerated such kinds as are mostly used by the trade, but my General Catalogue will be sent to any one applying for same, where you will find the most complete list of everything pertaining to Horticulture, and from which prices I allow liberal discount to the trade. As in former years, I will do my best to give you satisfaction, and retain the good will of the trade that I have always been favored with.

All correspondence, orders, etc., intended for me, please address to

Yours truly,

W. A. MANDA,

South Orange, N. J.

\section{DISCOUNTS.}

Prices in this Catalogue are net, except when cash is sent with the order, when I allow 5 per cent. discount.

Anything not found in this list, and ordered from my General Retail Catalogue, the Pocket Garden Directory of Everything Pertaining to Horticulture, which will be sent on application, I will allow the following discounts :

Flower or Vegetable Seeds, by the packet, 50 per cent.

Flower or Vegetable Seeds, by weight or measure, 25 per cent.

Flower or Vegetable Seeds, in collections or assortments, 25 per cent.

Plants and Bulbs, single, 33 per cent.

Plants and Bulbs, by dozen or ıoo, 20 per cent.

Plants and Bulbs, in collections, 20 per cent.

Trees, Shrubs and Vines, singly, 25 per cent.

Trees, Shrubs and Vines, by dozen or collection, 15 per cent.

Tools and Requisites, 10 per cent.

Books, Periodicals, etc., 10 per cent.

Special prices given on any article, quantity or quality. Read Terms of Payment before ordering. 
It is for the first time that hybrids of this very useful hardy rose are offered. They have been a great surprise to me, and to every one who has seen them.

They keep the same trailing habit, and the same fine green foliage, lasting well into January, and the same freedom of growth, some of them having made from a small cutting plant a shoot 18 feet 6 inches last season, and are therefore well adapted for any place, either to cover bare spaces on the ground, or for trailing purposes, for which they are invaluable.

As to flowers, they produce innumerable quantities of well formed blooms, lasting a long time in perfection, and flowering with such a freeness that no rose can equal it, so that a two or three year old plant can be fairly counted to produce a thousand or more flowers, and thus be a sight that can hardly be described.

As to hardiness they have stood the severe winter of 1 $895-96$ on a very exposed and bleak situation, without any covering whatever, and have flowered beautifully the following spring. They are not particular to any soil, but will grow even on the poorest gravelly and sandy banks, for which they are well adapted, not only for these purposes, but also as a pot-plant, either to force early in the spring or let it come naturally.

The variety named "Manda's Triumph" is well adapted for pot culture, as it is literally covered with a fine double white flower for several weeks. Taking them all in all, the set of four varieties represents a collection that should be in every garden, and which surely will prove even more valuable than the celebrated "Crimson Rambler."

\section{Manda's Triumph.}

This is a grand hybrid of free growth, with fine foliage and clusters of from twelve to eighteen flowers on even a small side shoot, literally covering the plant with its perfectly formed double white flowers, nearly two inches across, beautifully imbricated-a valuable sort, either for cut flowers or pot-plants. It is also very sweet scented-a valuable variety for florists.

\section{Universal Favorite.}

A free grower, producing long branching shoots, with bright shiny foliage in abundance, and soft light pink double flowers, two inches in diameter, strongly perfumed.

\section{South Orange Perfection.}

This is a gem, with free growth, close to the ground, and multitudes of the most perfectly formed double flowers, about one and a half inches in diameter, soft blush pink at the tips, changing to white.

\section{Pink Roamer.}

This is without question a hybrid between the Sweetbrier, and carries these characteristics in bloom, while the growth, which is very rampant, and the luxurious foliage, partake more of the Wichuriana. The single flowers, which are produced in close heads, are nearly two inches in diameter, bright rich pink, with almost a white centre, which lightens up the orange red stamens, producing an effect which, combined with the fragrance, makes it one of the most valuable roses in cultivation.

\section{PRICES.}

Plants to be delivered about the Ist of March, I897.

2 inch pot-plants, \$3.50 per doz., \$25.00 per hundred, $\$ 225.00$ per thousand.

Extra strong 3 inch pot-plants, \$4.50 per dozen, $\$ 35.00$ per hundred. 


\section{PRESS COMMENTS.}

From the American Florist, June 13,1896 - "W. A. Manda, South Orange, N. J., exhibited a most remarkable group of new roses, seedlings of Rosa Wichuriana, in foliage and habit exactly like Wichuriana, but the flowers of one are double white, another double pink, another shell pink, and one single pink. They are all beautiful acquisitions, lovely colors, and very fragrant. They created quite a sensation, and the Committee of Awards was requested to visit Mr. Manda and report on these beautiful novelties."

Florists' Exchange, June 13, 1896- "Mr. Manda had on exhibition some very interesting hybrids of Rosa Wichuriana, all showing double flowers, one especially being worthy of note-a cross between one of the hybrid perpetuals and the type, the true parentage not being known. The plant shows the floriferousness and habit of growth of R. Wichuriana, being even more vigorous. The flowers are white and are very symmetrical. Mr. Manda said, from a small cutting put out last July, on one branch he counted over 150 flowers, and the growth had now attained the length of eighteen feet six inches. Other hybrids shown had been fertilized by Noisette pullen, the result being some very

- pretty shades of color ranging from pink to white. Mr. Manda

- has also been crossing the Mlemorial rose with Meteor. Mme. Hosts, an 1 American Beauty, and the Sweetbrier, from which he hopes to obtain good results. The thanks of the club were tendered to Mr. Manda for his excellent exhibit."

The Florists' Exchange, June 27- "W. A. Manda was awarded honorable mention for a very promising hybrid Rosa Wichuriana." "W. A. Manda, South Orange, N. J., had an interesting display of orchids and herbaceous flowers, and received from the committee of the Gardeners' Society a certificate for his new double hybrid of Rosa Wichuriana, previously mentioned in these columns, and which he has named 'Manda's Triumph." "

II American Gardening, June 27-"New Kose, 'Manda's Triumph,' New York Gardeners' Society's certificate of merit to W. A. Manda, South Orange, N. J."

American Florist, June 27-"Brought out several very nice exhibits, among which that of W. A. Manda was particularly prominent. A hybrid of Rosa Wichuriana with double white flowers and dwarf habit gave promise of becoming a valuable addition to its class.

"To W. A. Manda (New York Gardeners' Society certificate), for new rose 'Manda's Triumph,' a hybrid from Wichuriana and an unknown $\mathrm{H}, \mathrm{P}$,

"Again shown and greatly admired-W. A. Manda's Wichuriana Hybrid, which received the award of honorable mention."

American Gardening, June 27-"Special mention must be accorded to W. A. Manda for his most interesting new hybrid rose ( $R$. Wichuriana $X$ hybrid perpetual variety). This 'Triumph,' as it has been named, was described on page 374 , issue of June $x_{3}$. It is satisfactory to learn that the Gardeners Society recognized its interest and made a suitable reward."

American Florist. July 18, 1896-" "The New York Florists' Club has, through its Coinmittee on Awards, given a silver medal and three certificates of merit to W. A. Manda for new roses."

The Florists' Exchange, July 18 - “The New York Florists' Club's Committee of Awards has recommended that the club's silver medal be awarded to W. A. Manda, South Orange, N. J., for his double hybrid of Rosa Wichuriana."

"The Committee of Awards of the New York Florists' Club visited the establishment of W. A. Manda, at South Orange, N. J., on June 15 , and examined his new roses. In their report of same they recommend certificates of merit to seedling No. 2, "a very pretty double rose, color a porcelain pink, two inches in diameter, of sweet fragrance, much like the old Sweetbrier, extremely strong grower and hardy;' to No. 3 , 'a rosy pink, with a large decided white eye, single bloom, two inches in diameter, and decided white eye, single bloom, two, inches in diameter, and ful double little rose, one inch in diameter, of a lovely blush pink color, a very strong grower and hardy.'

"They recommend a silver medal to No. 8, "the gem of the collection,' which might be called a double Rosa Wichuriana, color a pure white, and intensely double, very sweet fragrance, the foliage a deep shining green; of great substance; the growth is exceedingly strong and perfectly hardy.

"The committee consists of Eugene Dailledouze, chairman; Patrick O'Mara and Peter MacDonald.'

\section{AW ARDS.}

Manda's Triumph-Silver medal from the New York Florists' Club; Certificate from the New York Gardeners' Society; Honorable mention from Massachusetts Horticultural Society.

Universal Favorite-Certificate of Merit from the New York Florists' Club.

Pink Roamer-Certificate of Merit from the New York Florists' Club.

South Orange Perfection-Certificate of Merit from the New York Florists' Club. 


\section{BULBS.}

\section{AMERICAN CULTURE.}

In a large country like this, stretching from ocean to ocean, and embracing all the climates from perpetual snows to perpetual summers, of late years many bulbs, plants and seeds have not only been grown for home culture, but have been exported also, of which I offer the most important kinds below.

Per roo. Per 1,000 .

Tuberoses, double pearl, 4 to 6 inches..... \$1 oo $\$ 8$ oo

Freesias, Ist size................. $40 \quad 350$

" mammoth bulbs............. 60 . 550

“ Californian Giants............ 200

Calla Lily, good bulbs............... 6 oo

" mammoth bulbs............... 9 oo

“ Little Gem............... 6 o

“ extra large bulbs........... I2 0

Various Flower Seeds and Vegetab'e Seeds, Native Plants of all descriptions, Grass and Clover Seeds, prices on application.

\section{BERMUDA}

Furnishes the Easter Lilies and other miscellaneous products, of which I imported all on a large scale, and am ready to deliver now selected bulbs of

Per 100 . Per 1,000 . Lilium Harrisii, $5-7 \ldots \ldots \ldots \ldots \ldots \ldots \ldots . \$ 2$ oo $\$ 1 \$ 75$

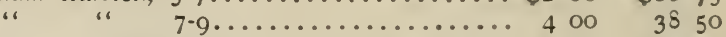

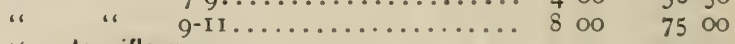

. Iongiflorum, $5-7 \ldots \ldots \ldots \ldots \ldots \ldots \ldots . \ldots \ldots 2500$

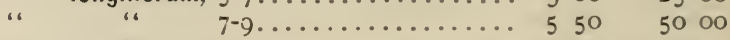

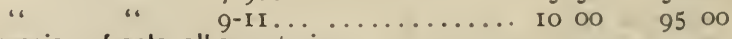

Freesia refracta alba. Ist size........... $40 \quad 375$

" " " extra selected, large, $50 \quad 450$

Oxalis Bermuda Buttercup, bright yellow.. $250 \quad 2250$

\section{GERMANY.}

The leading article imported from that country is extra selected Flower Seeds, a selection of which will be found on pages 14 to 17 , consisting of all those kinds that should be sown at present, while on Vegetable Seeds I would be pleased to give special quotation on any quantity or kind desired.

In bulbous plants the most important is

\section{Lily of the Valley.}

Per 1,000 . Case of 2,500 .

Fine Hamburg Pips................ \$9 00 \$22 00

Extra Early Berlin Crowns............ I0 00 2375

Special Bohemian Valley............. I2 $00 \quad 2800$

\section{AUSTRALIA.}

From Australia I import Palm Seeds, such as Kentias, some Arecas, etc., Zamias, Tree Ferns, and such plants which are generally offered upon arrival, a special list of which will be sent to any one desiring the same. 


\section{FRANCE.}

I was fortunate this year in making the largest contract in the history of Bulbs, especially so in French stock, which this year will be very scarce on account of the excessive drouth in that section, no rain having fallen there for a period of eight months, which will make the crop very short; but the quality will be much better, therefore giving better results when forced. Early orders solicited for the following :

(Prices subject to change.)

Per ז00. Per 1,000 . Roman Hyacinths. White, IO-II.......\$I 75 \$I6 OO

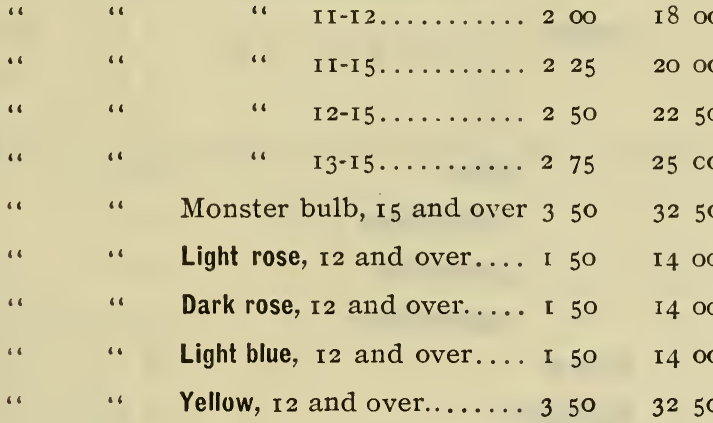

White Italian Hyacinths. Red skinned, I2-15. I $75 \quad$ I6 oo Narcissus. Paper white.............. $80 \quad 750$

" " " Grandiflora....... I oo 9 oo

“ Trumpet major............ I 25 10 oo

“ Von Sion. Excellent for early

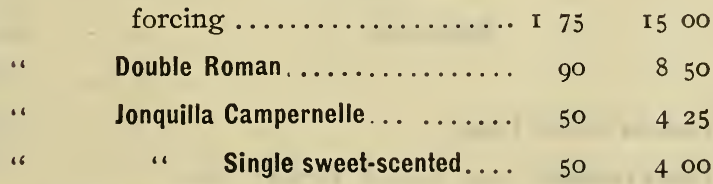

Lilium candidum. Large bulbs......... $250 \quad 2200$

Freesia refracta alba. Ist size........ $45 . \quad 375$

Allium Neapolitanum. Ist size......... $60 \quad 50$

Ornithogalum Arabicum.............. I $50 \quad$ I2 00

Anemone. Choice mixed............. $50 \quad 450$

Ranunculus. Choice mixed............ $30 \quad 275$

Gladiolus Colvellii tristis............... $250 \quad 2000$

Iris Hispanica. Yellow.............. $50 \quad 450$

Iris Hispanica. Blue................ 50 450

Lilac, pot grown, for forcing Chas. X... \$5 $\$$ oo $\$ 38 \infty$ 


\section{JAPAN AND CHINA.}

I am receiving direct importations from these two Eastern countries, which furnish us with so many beautiful bulbs and plants, and am therefore able to supply them at these extraordinarily low figures.

Per 100. Per 1,000 .

Lilium longiflorum, $\$ 2$ oo $\$ 1750$

“

7-9

375

3500

“

albo-narginatum, new... I 200 auratum,

275

2600

9-I I

425

4000

“

6

I I - I3

675

6500

6

16

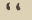

pictum.

o 00

‘ rubro-vittatum

$2 j 00$

, 6

platyphyllum.

IO 00

“

virginale album

2000

16

Brownii

2500

“ Batemannii.

500

“ elegans incomparable.

500

66 speciosum album, $7-9$

“ 6

“ 9 -II......... 600 5500

speciosum rubrum,

350

3300

6

“

$$
\text { 9-I I }
$$

$+75$

4500

“

Melpomene, 7-9

$+00$

3500

.

$$
\text { ‘ }
$$

9-I I .

600

5500

Chinese Sacred Lilies.... ........... + $25 \quad 4000$

Cycas revoluta, long leaved variety, fine, stout stems, 50c. to $\$ 2.50$ each.

Rhaphis humilis, pot grown, \$1. 50 to $\$ 4.00$ each.

.. flabelliformis, pot grown, \$r.50 to \$4.00 each.

New Japan Iris, 50 distinct varieties, 30c. each; \$14.00 for the set.

New Tree Pæony, 50 varieties, 75c. each; $\$ 35.00$ for the set.

Japan Maples, in finest variety, $\$ 28.00$ to $\$ 35.00$ per 100.

Any other Japan bulbs, seeds, trees or shrubs, price on application. 


\section{HOLLAND.}

The land of bulbs, where for the last two centuries these beautiful flowers have been largely cultivated, and from where I import largely all the specially selected stock, of which the following list are a few. On any variety not mentioned here, I will be pleased to furnish special prices on application.

\section{HYACINTHS.}

EXTRA SELECTED LARGE UNNAMED, MIXED. Single Dutch.

\begin{tabular}{|c|c|c|}
\hline Rose..... & $\begin{array}{l}\text { Per roo. } \\
\$ 250\end{array}$ & $\begin{array}{r}\text { Per } 1,000 . \\
\$ 2250\end{array}$ \\
\hline Dark Red. & 250 & \\
\hline White .... & 250 & 2250 \\
\hline Blush White & 250 & 2250 \\
\hline Light Blue . & 275 & 2500 \\
\hline Dark Blue & 250 & 2250 \\
\hline Yellow.... & & 2500 \\
\hline
\end{tabular}

Double Dutch.

Red. $250 \quad 2250$

White. $250 \quad 2250$

Blue $250 \quad 2250$

Yellow. $300 \quad 2750$

Single and double, all colors.

2252000

\section{Miniature Hyacinths or Dutch Romans.}

For bedding or forcing, these Hyacinths will be found equally as good as the more expensive named sorts.

\section{Single.}

Red.

Per roo. Per $x, 000$.

Rose \$I 25 \$II 50

Blush White

I 25 II 50

Dark Blue.

I 25 II 50

Light Blue.

Yellow. 


\section{FIRST SIZE EXTRA SELECTED NAMED.}

These Hyacinths are the very finest obtainable, and I feel confident that they will give every satisfaction.

\section{Single Red.}

Amy, fine carmine

Per doz. Per roo.

Baron Van Thuyll, fine rose. \$o 60 St 25

Chas. Dickens, fine red.

$75 \quad 500$

Gen. Pellisier, crimson

$60+50$

Gertrude, fine red ..

$75 \quad 500$

Gigantea, rose and blush.

$65+50$

Lord Macaulay, bright red............

$65+50$

Norma, nice pink.

$75 \quad 500$

Robt. Steiger, bright crimson.

$60+50$

$60+00$

\section{Single White.}

Alba superbissima, pure white ......... 60

Baron Van Thuyll, snow white.......... 50

Grandeur a Marveille, blush ........... 60

Grand Vainqueur, pure.............. $\quad 75$

Grand Vedette,

5

La Belle Blanchisseuse, fine........... 75

La Grandesse, best white............. I oo

Madame Van der Hoop, fine waxy........ 65

Mina

$65+50$

Mont Blanc, very fine white.

90600

$8_{5} 600$

\section{Single Blue.}

Baron Van Thuyll, violet blue ........... 60

Bleu Mourant, dark blue ............. 60

Charles Dickens, dark, light shading...... 60

Couronne de Celles, porcelain........... $S_{5}$

Czar Peter, porcelain blue............ 90

Gen. Pellissier

650

Grand Lilas .

Grand Maitre, light blue.

King of the Blues, very dark blue .........

Leonidas, porcelain blue, striped........

Marie, light blue and purple...........

\section{Single Yellow.}

Ida, extra fine yellow 
Double Red.

Bouquet Tendre, carmine red .........

Bouquet Royal, ..................... $75 \quad 5$ oo

Czar Nicholas, pink................ 60 450

Grootvorst, creamy blush............ 60 450

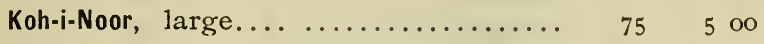

Princess Royal, red................. $75 \quad 5$ oo

Double White.

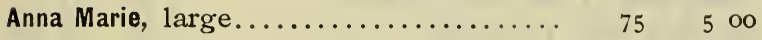

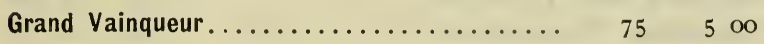

La Tour d'Auvergne, pure white.......... $75 \quad 500$

La Virginite, pale blush.............. 60 450

La Deese, pure white................ $75 \quad 500$

\section{Double Blue.}

Charles Dickens, bright blue.......... $75 \quad 500$

Garrick, rich purple.............. 60 450

Lord Wellington, dark blue.......... $75 \quad 5$ oo

Laurens Koster, dark................ $75 \quad 5$ oo

\section{Double Yellow.}

Goethe, sulphur yellow.............. \$o 80 \$6 oo

Jaune Supreme, rich yellow............ $80 \quad 6$ oo

Louis d'Or........................ 80 6 oo

Ophir d'0r....................... 80 6 oo

\section{LARGE SECOND SIZE NAMED HYACINTHS.}

These are generally sold as firsts, and are good solid bulbs, giving good results when forced. I can supply the following varieties at the uniform price of 50c. per doz, $\$ 3.50$ per 100 , and $\$ 32.50$ per 1,000 .

Single Red.

Amy, Baron Van Thuyll, Gertrude, Gigantea, No1 ma, Robt. Steiger.

\section{Single White.}

Alba superbissima, Baroness Van Thuyll, Grand Vedette, La Grandesse, La Pucelle d'Orleans, Madame Van der Hoop.

\section{Single Blue.}

Charles Dickens, Czar Peter, Grand Maitre, King of the Blues, La Peyrouse, Leonidas.

\section{Double Red.}

Bouquet Tendre, Grootvorst, Lord Wellington.

\section{Double White.}

La Deese, La Virginite, La Tour d'Auvergne.

\section{Double Blue.}

Blocksbergen, Garrick, Lord Wellington. 


\section{TULIPS.}

\section{Single Early.}

Per 100. Per 1,000 .

Duc Van Tholl. Common.............. \$o 45 \$ 425

“ “ “ Scarlet............ $40 \quad 375$

“ “ " Yellow............. 1 50 13 50

Artus. Brigbt Red............... 50 $50 \quad+25$

Belle Alliance. Scarlet................ 80 725

Canary Bird. Clear, rich, yellow........ I 25 I I 25

Cardinal's Hat. Dark red............ 50 \& 50

Chrysolora. Fine yellow........................... $95 \quad 85$

Couleur Cardinal. Red................ I $00 \quad 900$

Couleur Ponceau. Red and white........ $60 \quad 500$

Crimson King. Bright crimson, early.... 50 40

Cottage Maid. White and rose........... I 50 I3 50

Joost Van Vondel. Rose red and white... I o 9 co

Kaiserskroon. Red and yellow.................... $95 \quad$ S 25

La Reine. White and pink .......... 50 50 475

L'Immaculee. White.............. 60 500

Pottebakker. Yellow................ I 50 I 300

" White............... I 50 It 00

“ Scarlet.............. $95 \quad 850$

Proserpine. Fine, glossy rose......... I 75 I 500

Rose Grisdelin. Delicate rose........... I 50 I 300

Rosa Mundi Huykmann............... 95 S 50

Vermilion Brilliant. Dazzling vermilion... 2 oo 1750

Yellow Prince. Fine yellow.......... I 25 II 00

Manda's Choice Mixed. In finest varieties only............... $75 \quad 550$

Ordinary Mixture............... 40 375

\section{Double Tulips.}

Alba Maxima. Fine double white.......

\$I 50 \$1 300

Duc Van Tholl. Red and yellow........ 50 425

Imperator Rubrorum. Fine scarlet....... I 50 I 250

La Candeur. White.......................... $65 \quad 525$

Murillo. Fine light rose............ I 50 I3 50

Queen Victoria. White and red....... I 25 I2 00

Rex Rubrorum. Fine scarlet.......... I 50 I 50

Tournsoll, Red and Yellow............. I $50 \quad$ I2 50

Manda's Choice Mixed. In finest varieties

only $\ldots \ldots \ldots . \quad 75 \quad 550$

Ordinary Mixture............... $40 \quad 375$

\section{VARIOUS TULIPS.}

Per 100. Per 1,000 .

Bybloemens

\$o $75 \$ 650$

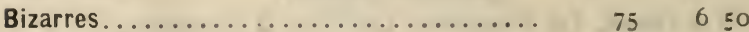

Gesneriana.............................. $65 \quad 55$

Darwin........................... $200 \quad 1800$

Parrot......................... $8_{5} \quad 750$ 


\section{Lilium Candidum. Northern Grown.}

This variety is far superior to the ordinary type, producing fine spikes of large flowers of great substance.

Per I00, $\$ 4.00$; per I,000, $\$ 35.00$

\section{NARCISSUS.}

\section{Polyanthus Narcissus.}

Per doz. Per roo.

Aurora. Yellow. \$o $35 \$ 200$

Chinese Sacred. White and yellow...... $75 \quad 425$

Grand Monarque. Pure white and orange. $\quad 30 \quad$ I 75

Grand Soleil d'Or. Orange yellow........ 30 I 75

Her Majesty. White and yellow......... 30 I 75

Jaune Supreme. Fine yellow........... $35 \quad 200$

La Citrionere. Fine yellow............ $35 \quad 200$

La Surprise. Fine white............ $35 \quad 200$

Queen Victoria. Yellow.............. $35 \quad 2$ оо

Staten General. White.............. 30 I 75

Paper White. Per I,000, \$7.50........ $20 \quad 90$

“ “ grandiflora. Per I,000, $\$ 9.00 \ldots 20 \quad$ I 00

\section{Single.}

Per ıоo. Per $\mathrm{x}, \infty 00$.

Bicolor Maximus $\$ 500$

Horsfieldii .

$400 \$ 3500$

Trumpet Major.

Poeticus.

$40 \quad 300$

“ ornatus

Golden Spur

Princeps

I 50 II 00

Incomparable. Yellow

$75 \quad 550$

Double.

Alba plena odorata \$o $75 \$ 50$

Incomparable fl. pl.

Von Sion.

I $75 \quad 1500$

Orange Phœnix

$200 \quad 1900$

Silver Phœnix

750

\section{CROCUS.}

Named varieties, any sort............... \$2 75

Large Yellow........................ 5 o

Fine mixed, any color................... I 75

\section{LILIES.}

I make a specialty of these the noblest of all bulbs, and can supply any varieties not found in this catalogue. Prices on application. 


\section{VARIOUS BEAUTIFUL AND INTERESTING BULBS.}

Per xoo. Per $x, \infty 00$

Allium Neapolitanum. Fine white....... \$o 65 \$5 50

Amaryllis Belladonna. Rose........... 6 oo

purpurea (Vallota). Scarlet..... 24 oo

Anemone coronaria. Choice mixed...... 50

". " Double ." ...... I 00

“ fulgens. Bright scarlet......... I 50

Arum sanctum (Black Calla). Black...... 700

Babiana. Fine mixed.............. 225

Bausingaultia baseloides............. ro oo

Brodiæa. Various kinds............. I 25

Bulbocodium vernum............... I 0

Calla æthiopica (Calla Lily), White...... 6 oo

." ." "Little Gem." Dwarf...... 600

Calochortus. Various kinds........... 200

Chionodoxa Luciliæ.................. I oo

Convallaria majalis (Lily of the Valley).

Strong crowns.............. I $\infty$

Crocus. (See page II.)

Crown Imperial. (See Fritillaria.)

Cyclamen persicum giganteum album....... 900

C. persicum giganteum roseum ........ 9 90

“ "

"، ". mixed........... 800

Daffodils. (See page Ir.)

Dicentra spectabilis (Bleeding Heart)..... 4 o

Eranthis hyemalis. Yellow............. 60

Erythronium. Mixed............. I 75

Eucharis amazonica. Pure white........ I8 oo

Freesia refracta alba. White........... 45

400

700

I2 00

900

900

" " Mammoth ....... 60

Fritillaria Imperialis (Crown Imperial) .... 500

Galanthus Elwesii (Giant Snowdrop)....... 75

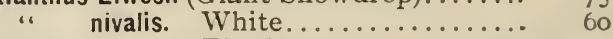

“ " Fl. pl.............. 90

Gladiolus, The Bride............... 50

Hyacinthus candicans................ 200

Ixia hybrida. Choice mixed colors....... 50

Leucojum vernum. Purple............. I 25

Lilium. (See page II.)

Narcissus. (See page II.)

Ornithogalum arabicum. White......... 200

0xalis Bowiei. Rose................ I 25

mixed, Various colors............ 50

Ranunculus. Fine double, mixed........ 50

Richardia æthiopica (White Calla)....... 6 oo

"، alba maculata. Yellow........... 700

Scilla bifolia. Blue.................. 60

". siberica. Blue................... 40

Sparaxis. Finest mixed colors........... 75

Spiræa japonica. White.............. 350

" " compacta multiflora........ 450

." astilboides. White............ 5 o

، .. floribunda............ I2 $\infty$

“ For other varieties see Herbaceous Perennials.

Sternbergia lutea. Yellow.............. I 50

Tritoma Uvaria grandiflora. Red........... 6 oo

Tritonia. Fine mixed colors.............. 20

Vallota purpurea. Scarlet, fine......... $24 \infty$ 


\section{DO NOT}

Be misled because you see the firm name of Pitcher \& Manda unchanged. Same firm, prior to my retirement, had been incorporated under that name, and I cannot prevent them from using it. You will find the original and only

\section{W. A. MANDA}

AT THE

\section{Universal Horticulitural Estabblishnment}

\section{SOUTH ORANGE, N. J.,}

where please address all letters and orders intended for me, as I am not in any way connected with the firm that still uses my name.

SEND ME A TRIAL ORDER. 


\section{CHOICE FLORISTS' FLOWER SEEDS.}

For IMMediate Sowisg.

From my personal experience I know the great importance of purity and high grade of stock. Therefore, I make it a special feature to handle only the very best strains. Purchasers may have every confidence in the quality of the seed I offer, and in ordering should order the best quality.

\section{Pansies, Show.}

Below you will find a list of the very finest of show pansies of incomparable size, beauty and luxuriance, especially my finest mixture.

In this mixture I have spared no pains in securing the finest strains and mixing carefully, only using those which I knew would give the best results. For size, coloring and abundance of flowers, this strain has no equal. They do best in summer in a cool, moist situation. Highly recommended for indoor culture in the winter.

Manda's finest mixture, extra selected strain, $\$ 6.00$ Per pkt. per oz............................ so 50

Extra fine choice mixed, good useful mixture...... 25

Ordinary mixture of standard varieties.......... 10

Odier, extra choice large blotched flowers....... 25

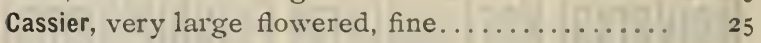

Bugnot's, superb fine strain............... 50

Superb mixture of the Odier, Cassier and Bugnot's strains. 25

English, choice mixture for general purposes..... 25

French fine strain of choice and bright colors.... 25

Trimardeau or Giant Pansies, enormous flowers, extra, 25

One packet of each of the above ro kinds for $\$ 1 . \$_{5}$.

\section{Pansies, Bedding.}

These differ from the above in their flowers being smaller, but they are produced in greater profusion. They form bushy plants covered with bloom, and are better adapted for bedding, as the color of the flowers is mostly solid in this class, and they are therefore better able to stand the sun than the fancy forms of the show pansies.

Cliveden, purple )

Per pkt.

“. white

“yellow

Azure Blue, choice, extra fine

King of the Blacks (Dr. Faust), very dark variety.....

Black Blue (dark blue), fine strain............. I5

Snow Queen (Candidissima), delicate satiny white.. 15

Light Blue, sky-blue.................. ${ }_{15}$

Lord Beaconsfield, very ective............. I5 
Per pkt.

Red Shades mixed, extra fine.............. \$o 15

Yellow, fine rich color for bedding............ I

Pure White, good form and clear color......... I5

Gold Margined, splendid variety............. I5

Silver edged (Atropurpurea albomarginata), charming. . 25

Violet margined with white, extra fine .......... 15

Choice mixture of Bedding Pansies, best varieties, I5

One package of each of the above 16 varieties for $\quad$ I 75

One packet of each Show and Bedding kinds, 26

packets, for.................... 325

\section{Cyclamen.}

These are among the most beautiful winter and spring flowering plants for the greenhouse.

Not only are the flowers very beautiful, but the leaves are very ornamental. The flowers run in shades from pure white to dark red.

Per pkt.

Persicum giganteum, finest mixed............ \$0 50

" " album. Pure white......... 50

" " atrorubrum. Dark red....... 50

" " $"$ roseum superbum. Extra fine... 50

" " " sanguineum. Darkest red..... 50

" " Manda's choice mixture.... . 50

One packet of each of the above 5 varieties for... 2 oo

\section{Cineraria.}

One of the most beautiful spring flowering plants for greenhouse or conservatory decoration.

When well grown, the flowers measure about two inches across, and cover the plant with a mass of bloom. Sow in late summer, in a light compost. When large enough, transplant in small pots, and shift as required. They do best when kept in a cool place, and will do well in a frame protected from frost.

Hybrida Grandiflora. Large-flowered, Choice Mixed, Per pkt. “" “

". Nana. Dwarf. Fine Strain... 50 Manda's choice mixture of the three strains...... 50 One packet of each of the above 4 kinds for..... I 50

\section{Calceolaria.}

Beautiful plants for greenhouse and conservatory decoration.

The curious pocket-shaped flowers are borne in the greatest profusion during the spring and summer. They vary greatly in color; some are self-colored, while others are beautifully spotted and blotched. Sow in late summer in shallow pans; transplant in thumb pots, and shift as required. They like a cool situation, and will do well in a frame protected from frost. 
Grandiflora. Large-flowered. Fine Strain........ Po po 50

“ Pumila Compacta. Dwarf. Self-colored. 50

“ Tigrina. Tigered or Spotted. Choice Mixed.................... 75

“ Tigrina Pumila Compacta. Dwarf....... 75

“ Striata. New Striped. Extra Fine... 50

Rugosa. (Shrubbery or bedding.) The true bed-

ding variety....................... 25

Manda's choice mixture of the above........... 50

\section{Primula (Primrose)}

One of the finest winter flowering greenhouse plants. The list below contains only the finest strains procured from the greatest specialist in Europe. Sow in early summer in shallow boxes or pans. When large enough, plant in small pots, and shift as required. They enjoy rather a cool position, and will do well in a frame protected from frost.

Per pkt.

Primula Chin. fimbriata rubra, red.............. \$o 50

“ " “ alba, white, excellent strain. . 50

" " " " $"$ " magnifica (Williams).... 75

" " " fringed, finest mixed, first quality............... 50

“ " " $\quad$ filicifolia, finest mixed....... 50

" " " "

“ “ “ fl. pl., double white, pure..... 75

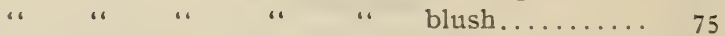

“ " "

“ " “ " " " " Manda's best mixed, 75

“ Auricula, fine, half hardy, perennial........ 25

“ Cashmeriana (capitata), quite hardy........ 25

“ Obconica, excellent for pots and bouquets... 25

“Elatior (veris), first quality, large flowered fancy................... Io

“ “ Duplex (Hose in Hose), very beautiful, Io

. “ gold-laced, charming varieties..... Io

“Verticillata, new, golden-flowered greenhouse plant...................... 50

“Vulgaris, the true Yeliow English Primrose.. Io One packet of each of the above for..........650

\section{Myosotis (Forget-me-not).}

This beautiful little plant is too well known to need any description. It does best in a cool, moist place, and can be used for spring bedding or winter flowering. The flowers when cut and placed in water will grow just as well as if on the plant. So 10

“ Alba, pure white................. I0

“ Robusta grandiflora (Elisa Fonrobert), large

" " $\quad$ Alba, white.......... 15 
Alpestris Victoria, dwarf, sky-blue flowers, the best

for pot culture............. \$o I $_{5}$

“ “ Alba, pure white, new.......... 15

Rupicola, porcelain, quite dwarf, excellent for pots, 20

One package of each of the above 7 varieties for.. $\quad 75$

\section{Mignonette (Reseda Odorata.)}

Odorata, good variety.................... 05

Grandiflora, large flowered, fine............. o5

“ Aurea (Golden Queen). Effective....... 05

“ Crimson Queen, red-flowered.......... 05

“ Gabrille, robust, red-flowered, fine..... Io

“ Gigantea pyramidalis (Giant Pyramida!)..... 05

“ Machet, excellent for pots, very fine.... Io

“ Multiflora compacta, very good......... 05

“ Pumila erecta, dwarf; excellent for pots, IO

“ Spiralis (Miles's Spiral). Beautiful. ..... - 05

Mixed, all varieties........................ 05

One packet of each of the above ro varieties for. . 50

\section{VEGETABLE SEEDS.}

I grow large quantities of all the leading vegetable Seeds, and will be pleased to quote low prices on application.

\section{PALM SEEDS.}

I am ready to book orders for Palm Seeds, and deliver same as soon as received from the collector. It is of great importance that Palm Seed should be fresh, otherwise it will not germinate, and, on that account, I never keep any on hand.

\begin{tabular}{|c|c|c|c|c|}
\hline & & $\begin{array}{l}\text { Per } \\
\text { see }\end{array}$ & $\begin{array}{l}\text { roo } \\
\text { eds. }\end{array}$ & $\begin{array}{l}\text { Per r,ooo } \\
\text { seeds. }\end{array}$ \\
\hline Areca & Baueri................. & \$o & 35 & $\$ 275$ \\
\hline “" & $\ldots \ldots \ldots \ldots \ldots \ldots$ & & 80 & 650 \\
\hline “ & ................. & & 45 & 350 \\
\hline Corypl & a australis. & & 35 & 275 \\
\hline Cocos & Weddeliana . & & Io & Io oo \\
\hline Kentia & Belmoreana... & & 80 & 700 \\
\hline “ & 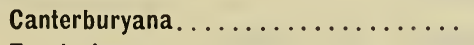 & 2 & 50 & 2000 \\
\hline “، & 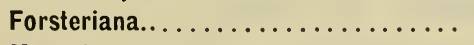 & & 80 & 700 \\
\hline “ & Moorei...................... & 25 & 50 & 2000 \\
\hline Latani & a Borbonica.................... & & 35 & 275 \\
\hline Seafor & 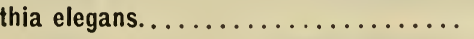 & & 35 & 275 \\
\hline
\end{tabular}

\section{GRASS SEED.}

I can furnish all the different Grass and Clover Seeds at current market prices, which I will give on application. I wish to draw special attention to

Manda's Universal Lawn Seed Mixture, which is specially prepared, and gives the best results.

Central Park Lawn Grass Mixture, per quart, Ioc.; per bushel, \$2.50.

Manda's Universal Lawn Seed Mixture, per quart, I $_{5}$ c. ; per bushel, \$3.50. 


\section{FLOWERING PLANTS.}

This useful class comprises both dwarf and climbing varieties. Only such are listed as have been found to be the best and most popular.

For other varieties see general catalogue.

\section{Azaleas.}

Strictly first-class stock in every respect, well set in bud, and the very best varieties, such as A. Borsig, Mme. Van der Cruyssen, Sigismund Rucker, Bernard Andre Alba, Deutsche Pearl, Imperatrice des Indes, Souv. de Prince Albert, Dr. de Moor, Emperor de Bresil, Concarde d'Orange, Simon Mardner, and Vervæneana.

Per 100.

First size, 9 to ro inches in diameter......... \$ \$ Second " 10 " 12 " " . ".......6 6000 Third " I2 $^{2} \mathrm{I}_{5}$ " $\quad \ldots \quad \ldots \ldots \ldots \ldots s_{5} 00$

Each.

Acacia. In best variety............. to $\$$. 100 Anthuriums. “ " $\quad \ldots \ldots \ldots \ldots \ldots \ldots \ldots \ldots$ s. to 200

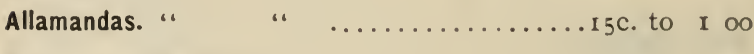

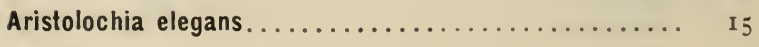

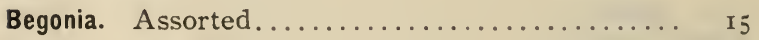

Baronia megestigma.................... 75

“ heterophylla................... 75

Clerodendron Balfourii. Nice plants............ 25

Dipledanias. In best varieties.............. 75

Ericas. In best varieties.. .............. 75

Gardenia florida. Strong plants............ 35

Genistas. All sizes..................... 50c. to 300

Imantophyllum miniatum. Strong..........50c. to I $\infty$

Pelargoniums. In variety............... I5c. to 50

Plumbago. In variety $\ldots \ldots \ldots \ldots \ldots \ldots \ldots \ldots \ldots$ I 5

Passiflora. Assorted....................... I $_{5}$

Reinwarthia tetragyne. Nice plants............ 25

Other flowering plants, size and price on application. 


\section{ORCHIDS.}

Beautiful beyond description, keeping well long after being cut, and of easy culture, have brought the Orchid into great demand as a cut flower, and no florist should be without them. Not only are they sold to the customer, but they act as a great advertisement, and a two-dollar Orchid in flower will attract more attention than anything you can have in the store or greenhouse. The prices of this fine class of plants vary according to size. Below are listed the best varieties for florists' use.

Cattleya citrina. Yellow flowers.......... \$O 50 to $\$ 150$

- intermedia. Free-flowering species. . I 50

“ Trianæ. The most useful variety.. I oo " 3 oo Cœlogyne cristata. Sprays, white flowers... I oo " 250 Cypripedium Boxallii. Flowers very freely.. I 50 " 250

“ Dauthierii. Blooms in the autumn............... I 50 " 250

“ Dominianum. Several flowers on a spike............. I oo " 250

، Harrisianum. Flowers twice every year.............. I 00 " 2 oo

“ insıgne. The best known of Orchids............... 50 " 200

، Lawrenceanum. Fine variegated foliage.............. 75 " 200

“ Sedenii. Beautiful pink flowers, 75 “ 2 oo

“ villosum. Free-flowering species............... I 50 " 250

Dendrobium nobile. One of the finest..... I oo " 250

“Wardianum. Fine winter bloomer............... I 25 " 250

Lælia albida. White flowers, borne on spikes, 75 “ I 50

“ anceps. Fine rose-colored flowers... 75 " 250

“ purpurata. Grand variety.......... I 75 " 500

Odontoglossum citrosum. Drooping spikes.. 75 “ 250

Rossii majus. Free-flowering variety............. 50 " 50

Oncidium varicosum Rogersii. Spikes of yel-

low flowers................... I 75

Zygopetalum Mackayii. Flowers very freely, I 50 " 250

Any other variety in any quantity. Price on application. 


\section{FOLIAGE PLANTS.}

The list below contains the best and most profitable sorts for Florists' use, and I can supply these in large quantities. Those desiring a more extended list can find almost anything in my retail catalogue.

Each.

Anthuriums, in variety..................... Si 0

Aralia Sieboldii. Fine plants ; 5 -inch pcts....... 45

Araucaria excelsa. Seedlings, I year old........ 25

" " $\quad$ I2 inches high.............. I 50

" " " 15 to 18 inches high........ 200

“ “ " glauca. I5 to 18 inches high.... 300

" " " I8 to 24 " " . ... + 40

Asparagus plumosus nanus. 6 -inch pots, strong..... 50

“ " “ 5-inch “ “ ... 35

Bromeliads, in fine varieties, from $\$$ I to $\$ 3$ each.

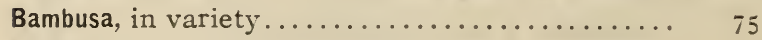

Begonias, assorted, 3 -inch pots.............. I2

Crotons, assorted, I $5 \mathrm{c}$. to $75 \mathrm{c}$.

Cryptomeria Japonica................... 45

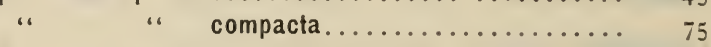

Dracæna, assorted, I 2 to 18 inches high......... $75^{\circ}$

" " $\quad$ I8 to 24 " “ “ $\ldots \ldots \ldots \ldots$ I 25

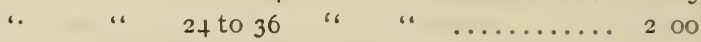

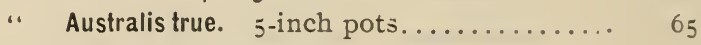

“ indivisa. 5 -inch pots............. 30

“ stricta. 5 -inch pots............. $6_{5}$

Ficus eiastica. Fine plants ; 45 c. to 65 c. each.

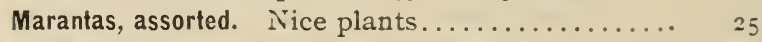

Phrynium variegatum. 3 and 4 -inch pots............ 15

Pandanus utilis. 3 -inch pots.................. I 8

" " 4 -inch " $\ldots \ldots \ldots \ldots \ldots \ldots \ldots \ldots . \ldots \ldots$

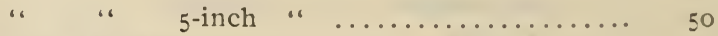

“ Veitchii. Fine plants, from $\$$ I to $\$ 5$ ea.

Schismatoglottis Roeblenii.................. 75

Other foliage plants, prices and sizes on application.

Fine plants for immediate effect, $25 \mathrm{c}$. to $\$ 1.50$ each.

\section{FERNS AND SELAGINELLAS.}

I offer a splendid assortment of th ase valuable classes of plants, mixed, suitable for filling jardinieres, fern cases, etc. Fine, strong-grown plants.

Assorted ferns and Selaginellas. 2-inch pots.. So 05

" " " " $"$ 3-inch “ .. of

Adiantum Farleyense. Fine plants, 2-inch “. .. I5

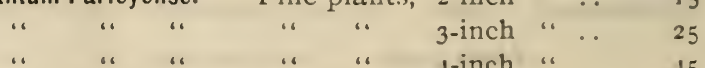

f-inch " .. 45

“ capellus veneris imbricatum. 2-inch “. ..

" " " $"$ " 3 -inch . .. 15

Cyrtomium falcatum. Fine plants, 3-inch “. . 08

Nephrodium molle cristata. " " 3 -inch " .. 08

Selaginella, in Iobest varieties, “ 2 -inch “ .. 05

" " $"$ " 4 3-inch " .. 08 


\section{PALMS.}

I have a very fine stock of Palms, comprising over thirty varieties, which have been grown cool, and are in good, strong, healthy condition. I have listed below the varieties that are most useful for Florists, and will be pleased to quote prices on any other variety on application. Measurements are taken as the plant stands from the ground.

Areca lutescens. Nice plants from $30 c$. to $\$ 5.00$, according to size.

Attalea mariposa, 2 inch pots $\ldots \ldots \ldots \ldots \ldots \ldots \ldots \ldots$

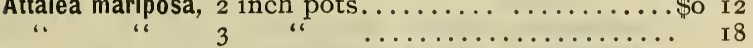

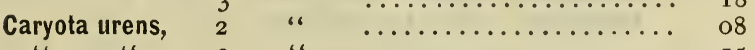

“" “ 3 “ “ $\ldots \ldots \ldots \ldots \ldots \ldots \ldots$. 15

Chamærops, many varieties, 2 inch pots.......... 8

“

“ Fortunii, 5 inch pots................. I 50

Cocos Maximiliana, $\quad 6 \quad$ “ $20 \ldots \ldots \ldots \ldots \ldots \ldots$ I 75

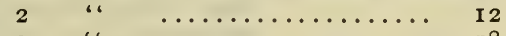

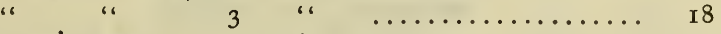

“ plumosa, 2 “ $\quad$ " $\quad \ldots \ldots \ldots \ldots \ldots \ldots \ldots$ I0

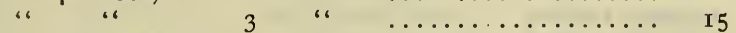

“Weddeliana, 3 " 3 nice plants..........

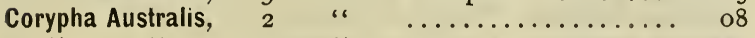

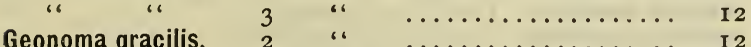

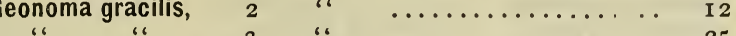

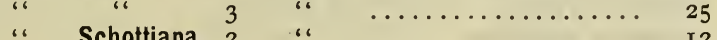

“" Schottiana, 2 “ “

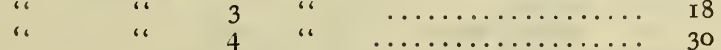

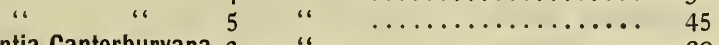

Kentia Canterburyana, 3 " $3 \quad \ldots \ldots \ldots \ldots \ldots \ldots \ldots, 20$

" “ 4 “ “ 4 .

" Belmoreana, 2 " $25 \ldots \ldots \ldots \ldots \ldots \ldots$. 12

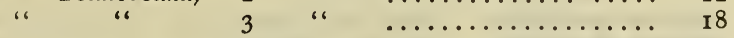

\begin{tabular}{|c|c|c|c|c|c|}
\hline & & & $\begin{array}{l}\text { Height, } \\
\text { Inches. }\end{array}$ & $\begin{array}{l}\text { Size of pot } \\
\text { Inches. }\end{array}$ & \\
\hline entia & Belmore & & ..18 to 20 & 4 to 5 & 75 \\
\hline & “" & & ....20 to 24 & 5 & I oc \\
\hline “" & “ & & ….....24 to 28 & & I 25 \\
\hline “" & “، & .... & $\ldots \ldots \ldots \ldots 28$ to 30 & 6 & \\
\hline “" & “ & .... & ......... 30 to 32 & 6 & \\
\hline “" & “" & $\ldots$ & $\ldots \ldots \ldots \ldots 32 \mathrm{t}$ & 6 & 350 \\
\hline “ & “. & & .......... 36 to 48 & 7 to 8 & 5 to 8 \\
\hline “، & Forsteriana. & & .........20 to 24 & 5 & 65 \\
\hline “، & “ & & $\ldots \ldots \ldots \ldots 24 t$ & 5 & I oc \\
\hline “ & “ & & .......30 to 35 & 6 & \\
\hline “" & ، & & $\ldots \ldots \ldots 35$ to 40 & 6 & 2 oc \\
\hline “، & “" & & $\ldots \ldots \ldots \ldots 40$ to 45 & 6 & 25 \\
\hline $\tan$ & Borbonica & $\mathrm{a}, 2 \mathrm{i}$ & ch pots. & & o8 \\
\hline “. & “ & 3 & & & I5 \\
\hline “ & “" & 4 & & & \\
\hline & " & 5 & & & \\
\hline ، & “" & $\begin{array}{l}5 \\
6\end{array}$ & $\cdots \cdots \cdots \cdots$ & ( & \\
\hline
\end{tabular}

Phœnix in ten varieties, 2 inch pots..............

" " 3 " $\quad \ldots \ldots \ldots \ldots \ldots$. 15

I have a good stock of larger plants, prices of which I will be pleased to quote on application.

\section{CYCADS.}

Cycas revoluta. Fine plants from $\$ 2.00$ to $\$ 5.00$ each.

Zamia integrifolia " " I. 50 to 3.00 " 


\section{HARDY HERBACEOUS PERENNIALS}

With a good assortment of Hardy Perennials, flowers can be had from early spring until frost cuts down all vegetation. For florists this class of plants is invaluable. Once planted they need very little care. I make a specialty of Hardy Herbaceous Plants, and devote a large tract of land to their culture. A visit to the nursery during summer will surely be of interest.

Achillea, “The Pearl.' Flowers pure white................. \$o 75 \$4 00

“ millefolium rubrum. Rose-color.... I 00

“ tomentosa. Fine lasting sort, yel. low..................... I oo 6 oo

Agrostemma coronaria. Fine flowers........ I , 00 . 6 oo

Alyssum argenteum. Yellow flowers in spring ................. I 75 I 2 oo

Anemone Japonica. Rose-colored flowers. I $00 \quad 600$ " " Alba. Pure white, late. I 00600 " "Whirlwind. Semi-double, extra fine......... I $25 \quad 900$

Aquilegia hybrids. A fine assortment...... I oo 6 oo

Artemisia pontica. Silvery leaves........... 75 + 75

Asclepias tuberosa. Flowers orauge....... I $100 \quad 6$ oo

Baptisia Australis. Fine blue flowers...... I 1 . $00 \quad 600$

Berberis aquifolium. Spiny-toothed leaves. $250 \quad 1800$

Centranthus ruber. Fine Pink flowers..... I $50 \quad 900$

Coreopsis lanceolata. Yellow, very florif-

erous..................... I $\infty \quad 500$

Harvest Moon. A fine variety... I 50 . 900

Delphinium sinense. Flowers white and blue...................... I 00 600

Dianthus plumarius plenus roseus. Sweetscented, Scotch Pinks ........ I 00 I 600

Dicentra spectabilis.. Bleeding Heart..... I 00 . 6 oo

Digitalis gloxinoides. Fine for cutting..... I 00 , 6 oo

Doronicum plantagineum excelsum. Yellow; flowers early............... I 75 I 200

Eryngium amethystinum. Globose heads.... I

Elymus Glaucus. A glancus-leaved grass.. I $50 \quad 900$

Eulalia japonica variegata. Variegated white

“ „ . $\quad$ and green...............

run-

Euonymus radicans, a trailing, shrubby plant for edgings... I $50 \quad \S 00$

“ “ variegata, a variegated form; very fine.... I 50 \& 80

Euphorbia corollata. White flowers....... I 00 , 600

Funkia undulata variegata. Fine for edging. I 00 600

Gaillardia grandiflora. Yellow, with rings of
crimson : flowers all season......... I $50 \quad 800$

Glechoma hederacea variegata. Fine trailing plant, or for vases................ I oo 600

Helianthus Maximilianii. Flowers very late. I $50 \quad \varepsilon 00$

“ multiflorus maximus........... I $50 \quad \& 00$

“ multiflorus plenus. Fine for cutting. I 00600

“ multiflorus grandiplenus. Improve- 1 oo 6 oo

“Soleil d'0r. New, extra fine..... I 75 i2 0

“ orgyalis. Large panicles of yellow 50 If 00

Hypericum Moserianum. Fine yellow flowers. I 75 I 200

Hemerocallis flava. Sweet-scented, yellow. I $50 \quad 800$

Hollyhocks. Very finest double sorts.... I 50 io 00

Iberis sempervirens. White, fragrant flowers $\quad$ I $00 \quad 600$ 
Per doz. Per roo.

Iris Germanica mixed. Fine for cutting.... \$o 75 \$4 $\quad$ \$o

" " named. Extra fine varieties I oo 6 oo

“ Kæmpferii mixed. Fine for cutting..... $75 \quad 400$

" " named. A fine assortment.. I oo 6 oo

"pseudo-acorus variegata. Variegated

leaves ; fine, bold plants......... I 50 Io oo

Monarda didyma. Crimson flower heads... I oo 600

Myosotis palustris semperflorens. Flowers

all seasons.................... I oo 6 oo

Enothera fruticosa, deep yellow flowers.... I $50 \quad 800$

" Missouriensis, extra fine variety.. I $50 \quad$ o 80

Pachysandra terminalis, a fine green bedding plant................................... 250 ro on

Pæonies, choice mixed $\ldots \ldots \ldots \ldots \ldots \ldots \ldots$ I 75 I2 00

“ Extra large clumps .......... 5 oo

Papaver Alpinum, white, yellow and rose... I 50 ro oo

“ nudicaule, early; very floriferous. . I oo 600

“ Orientale, bright, scarlet flowers... I $50 \quad 800$

Phlox paniculata named, extra fine sorts.... I 50 o 800

“ " " mixed, good varieties...... $75 \quad 400$

“ ". The Pearl, the best white

Phlox.............. I oo 6 oo

" subulata, a prostrate species; fine... I oo, 500

Polygonum cuspidatum. Feathery white.... I 50 8 oo

Primula elatior in varieties. Fine......... I 50 . 900

Pyrethrum roseum named. Fine for cutting. 225 I5 00

" " seedlings. " " $\quad$ I 50 " 900

" uliginosum. Grand Fall plant.... I $50 \quad 800$

Rosa Wichuriana. A fine trailing rose.... I $50 \quad 900$

Rudbeckia speciosa. Fine for cutting...... I 50 800

Sedum spectabile. Rosy purple flowers.... I oo 600

Spiræa filipendula flore pleno. White....... I 50 . 800

Tunica saxifraga, pink flowers........... I oo 6 oo

Vinca minor. Trailing plant for rockwork I oo 500

Special prices for extra large quantity, or any other variety.

\section{TREES, SHRUBS AND VINES,}

Both ornamental and fruit, are grown largely by me, and I would be pleased to quote special prices on any quantity, size or variety you may need in your trade. I can supply you fine stock from 8c. upwards, and would be pleased to receive a list of your wants.

\section{CARNATIONS.}

I grow all the leading kinds of Carnations, and can furnish strong field-grown plants at very reasonable prices, in the very finest varieties, such as Wm. Scott, Lizzie McGowan, Storm King, Helen Keller, Portia, and all others. Price on application.

\section{VIOLETS.}

Florists who have failed to grow their violets are advised to send me the number of plants they need, and I will quote low prices for clean, healthy stock.

Do not be misled because you see the firm name of Pitcher \& Manda unchanged. Same firm, prior to my retirement, had been incorporated under that name, and I cannot prevent them from using it. You will find the original and only

$$
\text { W. A. MA N D A }
$$

AT THE

\section{Universal Horticultural Establishment,} SOUTH ORANGE, N. J.,

where please address all letters and orders intended for me, as I am not in any way connected with the firm that still uses my name. 


\section{NOVELTIES AND SPECIALTIES.}

\section{Lilium Longiflorum Albo-Marginatum (The Chotaro Lily).}

This is the greatest novelty in the bulb line. The flowers are as large as the well known Lilium Longiflorum, while the luxuriant foliage has a broad margin of silvery white, which combines well with the w'site flowers, giving the plant a unique appearance. Stock limited. Order early. Per doz., \$1.75; per IOO, \$I 2.

\section{Adiantum Capillus-Veneris Imbricatum (The Hardy Farleyense).}

This is a grand acquisition to the Ferns. In general appearance it rivals the famous Adiantum Farleyense, besides being a free grower and of much hardier constitution, and on that account well adapted to general culture, and especially for fern dishes. Should be grown by every one. Received three first-class certificates in Boston, Lenox and New York. Order early.

Nice plants in 2-inch pots, \$I.25 per ro; \$ro per 100.

\section{Spiræa astilboides floribunda.}

This grand new plant is as useful for forcing as for herbaceous border. It is in the same relation to $\mathrm{S}$. astilboides as is S. japonica floribunda to the common S. japonica. The plant is compact, furnished with numerous spikes closely set with pure white flowers. A plant I can strongly recommend. Per doz., \$1.75; per 100, \$1 2 .

\section{Coreopsis lanceolata (Harvest Moon).}

A grand improvement on the well-known species, and one that should be in every collection of Hardy Plants. The habit and flowers are much larger and stronger. Well adapted for cutting purposes. Per Io, \$1.25; per I00, \$8.

\section{PURE SHEEP MANURE.}

I am greatly pleased to say that I have secured a large quantity of the very best sheep manure, perfectly pure and unadulterated, free from all straw or litter of any kind, which is generally found in most of the other grades.

I can safely say that it is the finest quality offered in the market. There is nothing can equal this manure for greenhouse purposes, such as top dressing roses, carnations, chrysanthemums, or any other plants that are strong feeders.

And there is nothing better for mixing through potting soil or for making liquid.

It is also the finest manure for top dressing lawns or for the manuring of fields or gardens.

In all respects it is par excellence. For top dressing greenhouse plants, use equal proportions of manure and good loam. For mixing through potting soil, use one part manure to nine parts loam. For making good liquid, use about ten pounds to the barrel. For lawns, fields or gardens, use about one pound to ten square feet, or two tons to the acre. $25 \mathrm{lb}$. bag, 60 cents; roo lb. bag, $\$ 2.00$; per ton, $\$ 28$. 


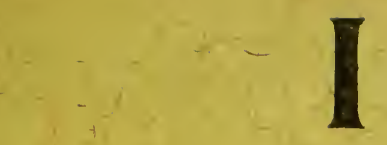

\section{IMPORT}

DIREOT FROM

AFRICA,

AUSTRALIA,

BELGIUM,

BERMUDA,

CENTRAL AMERICA,

ENGLAND,

EAST INDIES,

HOLLAND, $;,$ GERMANY,

JAPAN,

SOUTH OF FRANCE,

SOUTH AMERICA,

WEST INDIES,

FOR FLORIST TRADE.

SEEDS, PLANTS 积 BULBS OF FLL DESGRIPTION IN LARGE QUANTITY.

If you are interested in any of the above, send me jour name,

and I will place same on a Special List, and notify you of every Importation, with

Special Low Quotation. 


\section{W. A. MANDA,}

Horticultural Expert,

MERCHANT, GROWER, IMPORTER

AND EXPORTER IN

Flower, Vegetable, and Grass Seeds, Greenhouse and Hardy Plants and Bulbs, Trees, Shrubs, .. and Vines. .

\section{$\dot{\Delta} \hat{\Delta}$ \\ Novelties a Specialty. $\because:$ :}

Landscape Architect, Horticultural Builder, Adviser and Valuer.

Winner of ozer 500 Medals, Diplomas, and Money Prizes at all the leading Horticultural Exhibitions in America.

ACTIVE MEMBER OF

Massachusetts Horticultural Socicty,

Pennsylvania Horticultural Society,

Lenox Horticultural Society,

New Jersey Horticultural Society,

Society of American Florists,

New York Florists' Club (Ex-President),

Philadelphia Florists' Club.

HONORARY MEMBER

Minnesota Horticultural Socicty,

Berkshire County Gardeners' and Florists' Club, Boston Gardeners' and Flurists' Club.

\section{FORMERLY}

Ourator Botanical Gardens of Harvard University, Cambridge, Mass.

Managing Partner PITOHER \& MANDA (lately incorporated Stock Oompany).

NOW

PROPRIETOR OF THE

Universal Horticultural Establishment, SOUTH ORANGE, N. J. 